\title{
Entre la autonomía y la autarquía del Jurado Nacional de Elecciones: la irrevisibilidad de sus decisiones en sede jurisdiccional en cuestión
}

A propósito de la modificación introducida por el Congreso de la República al Código Procesal Constitucional y el precedente vinculante establecido por el Tribunal Constitucional peruano

Christian Donayre Montesinos

\section{Una aproximación a la controversia generada entre el Tribunal Constitucional y el Jurado Nacional de Elecciones}

Una lectura literal de los artículos 142 y 181 de la Constitución peruana vigente conduciría a admitir que en nuestro país existen zonas exentas de control constitucional, lo cual no se condice con el concepto mismo de Constitución. ${ }^{1}$ En efecto, de acuerdo con lo establecido textualmente en aquellas disposiciones, las resoluciones del Jurado Nacional de Elecciones en materia electoral, así como las decisiones del Consejo Nacional de la Magistratura en lo relativo a la evaluación y ratificación de jueces y fiscales, serían irrevisables en sede judicial. $^{2}$

Si aceptamos que en un Estado constitucional un elemento fundamental es el control y la limitación del poder para asegurar así la vigencia efectiva de los

Profesor titular de Derecho Constitucional de la Pontificia Universidad Católica del Perú y profesor asociado de la Academia de la Magistratura.

1 Sobre el particular resulta del mayor interés revisar ARAGón ReYES, Manuel. El control como elemento inseparable del concepto de Constitución. En Revista Española de Derecho Constitucional, $\mathrm{n}^{\circ}$ 19. Madrid: Centro de Estudios Constitucionales, 1987, p. 17 y ss. Y del mismo autor, Constitución y control del poder. Buenos Aires: Ediciones Ciudad Argentina, 1995, pp. 11-65.

2 Así, conforme explicitan los artículos 142 y 181 del texto constitucional vigente: «No son revisables en sede judicial las resoluciones del Jurado Nacional de Elecciones en materia electoral, ni las del Consejo Nacional de la Magistratura en materia de evaluación y ratificación de jueces» (artículo 142 de la Constitución de 1993). «El Pleno del Jurado Nacional de Elecciones aprecia los hechos con criterio de conciencia. Resuelve con arreglo a ley y a los principios generales del derecho. En materias electorales, de referéndum o de otro tipo de consultas populares, sus resoluciones son dictadas en instancia final, definitiva, y no son revisables. Contra ellas no procede recurso alguno» (artículo 181 de la Constitución de 1993). 
derechos fundamentales, ${ }^{3}$ coincidiremos entonces en la preocupación que nos genera una lectura literal de lo dispuesto en los preceptos constitucionales antes referidos. Es más, dicha preocupación aumenta si somos concientes de que en aquellos espacios pueden, eventualmente, verse amenazados o vulnerados precisamente los derechos fundamentales — como de hecho ha ocurrido-, y las personas no contarían, en principio, con un mecanismo procesal sencillo, rápido y efectivo para exigir su tutela en sede jurisdiccional, tal como lo exigen incluso los tratados internacionales de los cuales nuestro país es parte. ${ }^{4}$

Afortunadamente, en líneas generales la preocupación muy sucintamente descrita líneas atrás, suscitó más de un interesante pronunciamiento del Tribunal Constitucional peruano. Y es que este Alto Tribunal, dejando de lado aquella lectura literal de la Carta de 1993, admitió mediante sendas demandas de amparo la revisión por los tribunales de justicia tanto de las decisiones del Consejo Nacional de la Magistratura en lo que concierne a la evaluación y ratificación de jueces y fiscales, así como las que emitiera el Jurado Nacional de Elecciones en materia electoral.

En el caso del Consejo Nacional de la Magistratura, el supremo intérprete de nuestra Constitución conoció de diversas demandas de amparo. En algunas de ellas ciertos jueces cuestionaban el hecho de que se les haya sometido a un procedimiento de ratificación pese a no haber cumplido aún el plazo de siete años en el ejercicio de sus funciones, ${ }^{5}$ tal como exige el mismo texto

3 Las tres manifestaciones del control y la limitación del poder como parámetro propio de todo Estado constitucional que se precie de serlo, es decir, el imperio de la ley, el sometimiento de la Administración al principio de legalidad y la separación o división de poderes, son muy bien desarrolladas en el trabajo de Díaz, Elías. Estado de derecho y sociedad democrática. Madrid: Taurus, 1969, p. 31 y ss. Sobre el particular también puede revisarse Zagrebelsky, Gustav. El derecho dúctil. Ley, derechos y justicia. Madrid: Trotta, 1995.

4 Dada la importancia que adquieren los derechos fundamentales para la vigencia de un Estado y el desarrollo de los seres humanos en tanto su fin último, es menester reconocer una serie de mecanismos y canales procesales a través de los cuales los ciudadanos puedan encontrar protección cuando consideren que sus derechos vienen siendo amenazados o lesionados. Precisamente para evitar que el reconocimiento de los derechos sea mera retórica, en tanto su lesión puede devenir finalmente en irreparable y el agraviado no tener a mano mecanismos que satisfagan su requerimientos, los diferentes instrumentos internacionales de protección de los derechos humanos de los cuales el Perú es parte han recogido el derecho de toda persona a un recurso sencillo, rápido y efectivo; y como contrapartida, la obligación de todo Estado de así contemplarlo.

En ese sentido encontramos el artículo 8 de la Declaración Universal de Derechos Humanos, el artículo 25 de la Declaración Americana de Derechos y Deberes del Hombre, el inciso 3 del artículo 2 y, para el caso de los detenidos, el inciso 4 del artículo 9 del Pacto Internacional de Derechos Civiles y Políticos, y en la Convención Americana sobre Derechos Humanos el artículo 25 y el inciso 6 del artículo 7, para el supuesto de los sujetos privados de su libertad.

5 Puede revisarse sobre el particular las sentencias del supremo intérprete de nuestra Constitución recaídas en casos como el «Diodoro Antonio Gonzáles Ríos» (expediente 24092002-AA/TC); «César Sebastián Hinostroza Pariachi» (expediente 065-2003-AA/TC); y «Raúl Sebastián Rosales Mora» (expediente 216-2003-AA/TC). 
constitucional. ${ }^{6}$ Otros iniciaban dicho proceso constitucional por la falta de motivación de las resoluciones de no ratificación emitidas por este organismo constitucionalmente autónomo. ${ }^{7}$ Por último, había quienes presentaron sus respectivas demandas debido a que en ningún momento se les convocó a audiencia para que ejerzan su derecho de defensa y, a pesar de ello, no se les ratificó en el cargo. ${ }^{8}$

Cuestionamientos como los expuestos por parte de algunos jueces, así como las sentencias que sobre el particular emitió el Tribunal Constitucional peruano, condujeron a que hoy en día la ley 28237, más conocida como Código

Ahora bien, sobre el sometimiento a un procedimiento de ratificación a un juez que todavía no había cumplido el plazo de siete años en ejercicio de sus funciones porque, por ejemplo, había sido suspendido, el supremo intérprete de nuestra Constitución precisó que dicho lapso de tiempo debe, en primer lugar, computarse desde la entrada en vigencia de la Carta de 1993, y, en segundo término, si el demandante estuvo suspendido no es posible considerar el tiempo de la suspensión para efectos del cómputo de los siete años que exige el texto constitucional.

6 Así, de conformidad con lo estipulado en el inciso 2 del artículo 154 de la Constitución peruana vigente, corresponde al Consejo Nacional de la Magistratura ratificar a los jueces y fiscales de todos los niveles cada siete años.

7 Véase al respecto los pronunciamientos del Tribunal Constitucional peruano en casos como el de «Luis Felipe Almenara Bryson» (expediente 1941-2002-AA/TC) y «Mario Antonio Urrello Álvarez» (expediente 2209-2002-AA/TC).

En cuanto a la falta de motivación de las decisiones del Consejo Nacional de la Magistratura en materia de ratificaciones judiciales, el supremo intérprete de nuestra Constitución era de la opinión que el mecanismo de ratificación conducía a que el Consejo pueda emitir un voto de confianza o de no confianza respecto de la manera como el juez evaluado se ha desempeñado en el cargo. Es más, sostenía que esa ha sido la intención indubitable de los constituyentes de la carta de 1993, esto es, consagrar la no motivación de las ratificaciones judiciales. Estamos, como bien podrá observar el lector, ante una postura a todas luces discutible, y que afortunadamente lo planteado actualmente en el Código Procesal Constitucional permite dejar de lado, ya que en caso el Consejo Nacional de la Magistratura no motive sus resoluciones en materia de ratificaciones judiciales o fiscales, será posible iniciar un proceso de amparo contra esa decisión de dicho organismo constitucionalmente autónomo.

8 Sobre este tema pueden revisarse las sentencias del Tribunal Constitucional peruano recaídas en casos como el «Rosa Rolando Ramírez» (expediente 2952-2002-AA/TC) y «Walter Peña Bernaola» (expediente 2859-2002-AA/TC). En estos supuestos el supremo intérprete de nuestra Constitución asumió una posición cuestionable, pues sostuvo, por un lado, que en estos casos la resolución de no ratificación no resultaba aplicable, y por otro, declaró infundado el pedido de reposición en el cargo formulado por los jueces y se limitó a señalar que se les conceda la audiencia contemplada en la ley.

La discutible configuración de las ratificaciones judiciales y fiscales en el esquema peruano ha sido materia de múltiples e interesantes trabajos. Puede revisarse al respecto, entre otros, Abad Yupanqui, Samuel. Ratificaciones judiciales zun poder discrecional, secreto e incuestionable?; Palomino Manchego, José F. Los criterios interpretativos del Tribunal Constitucional en relación con las ratificaciones judiciales; EsPINOSA-SALDAÑA BARRERA, Eloy. ¿Conviene mantener la irrevisibilidad de las resoluciones del Consejo Nacional de la Magistratura sobre ratificaciones judiciales y fiscales?; MORALES GODO, Juan. La ratificación de los magistrados y el Estado Constitucional; CARPIO Marcos, Edgar. El control jurisdiccional de las ratificaciones judiciales; y SORIA LuJÁN, Daniel. La ratificación de magistrados: zuna zona exenta de control constitucional?; todos ellos, y en ese orden, publicados en Diálogo con la Jurisprudencia, año 9, nº 52, Lima: Gaceta Jurídica, enero 2003, p. 23 y ss. 
Procesal Constitucional, recoja en el inciso 7 del artículo 5 que cabe plantear una demanda de amparo contra una decisión del Consejo Nacional de la Magistratura en materia de destitución y ratificación de jueces y fiscales, siempre que dichas resoluciones no hayan sido motivadas o dictadas sin previa audiencia al interesado. ${ }^{9}$

En relación con el Jurado Nacional de Elecciones, el supremo intérprete de nuestra Constitución en el célebre caso "Juan Genaro Espino Espino» (expediente 2366-2003-AA/TC ${ }^{10}$ señaló:

Este Tribunal, por consiguiente, debe enfatizar, al igual como lo hiciera respecto de las resoluciones emitidas por el Consejo Nacional de la Magistratura en el Exp. No 2409-2002-AA/TC (Caso Gonzales Ríos) y la posibilidad de un control jurisdiccional sobre ellas, que no cabe invocar la existencia de campos de invulnerabilidad absoluta al control constitucional, so pretexto de que la Constitución confiere una suerte de protección especial a determinadas resoluciones emitidas por parte de determinados organismos electorales. En efecto, aun cuando de los artículos $142^{\circ}$ y $181^{\circ}$ de la Norma Fundamental, se desprende que en materia electoral no cabe revisión judicial de las resoluciones emitidas por el Jurado Nacional de Elecciones, y que tal organismo representa la última instancia en el asunto, dicho criterio sólo puede considerarse como válido en tanto y en cuanto se trate de funciones ejercidas en forma debida o, lo que es lo mismo, compatibles con el cuadro de valores materiales reconocido por la misma Constitución. Como es evidente, si la función electoral se ejerce en una forma que resulta intolerable para la vigencia de los derechos fundamentales o quebrante los principios esenciales que informan el ordenamiento constitucional, no sólo resulta legítimo sino plenamente necesario el control constitucional, especialmente cuando este resulta viable en mecanismos como el amparo. (sic)

Esta fue la primera ocasión en la que nuestro Tribunal Constitucional entró a pronunciarse respecto de la revisibilidad de las decisiones del Jurado Nacional de Elecciones. Ahora bien, como ocurrió con el Consejo Nacional de la Magistratura, con posterioridad el Código Procesal Constitucional consagró en el artículo 5 , en donde se regulan las causales de procedencia o improcedencia de

\footnotetext{
En efecto, el Código Procesal Constitucional nos dice al respecto que:

«No proceden los procesos constitucionales cuando:

$[\ldots]$

7) Se cuestionen las resoluciones definitivas del Consejo Nacional de la Magistratura en materia de destitución y ratificación de jueces y fiscales, siempre que dichas resoluciones hayan sido motivadas y dictadas con previa audiencia al interesado;

$[\ldots] »$.

10 Sentencia de fecha 6 de abril del 2004 y publicada el 7 del mismo mes y año.
} 
los procesos constitucionales de la libertad ${ }^{11}$ que sería posible plantear una demanda de amparo contra las resoluciones de carácter jurisdiccional del Jurado Nacional de Elecciones en materia electoral, cuando vulneren la tutela procesal efectiva. ${ }^{12}$

No obstante, el consagrar en una ley la posibilidad de que las decisiones del Jurado Nacional de Elecciones puedan eventualmente ser revisadas a través de un amparo, tal como lo hace la ley 28237, no fue bien visto sobre todo por las autoridades vinculadas con dicha institución. Tanto es así que por iniciativa del mismo Jurado Nacional de Elecciones, en septiembre de 2005, se presentó un proyecto de ley en el sentido de modificar aquel inciso del artículo 5 del Código, estableciéndose como propuesta alternativa la siguiente disposición:

Artículo 5०.- Causales de improcedencia.

No proceden los procesos constitucionales cuando:

$[\ldots]$

8. Se cuestionen las resoluciones del Jurado Nacional de Elecciones.

[...].

Luego del debate llevado a cabo en la sede del Congreso de la República, se aprobó finalmente un texto que va en el sentido propuesto por el Jurado. En efecto, con fecha 8 de diciembre de 2005, se publicó la ley 28642, que modifica el Código Procesal Constitucional y proscribe la procedencia de los procesos constitucionales interpuestos contra resoluciones del Jurado Nacional de Elecciones. El texto quedó como sigue:

11 En doctrina frecuentemente se distingue entre jurisdicción constitucional de la libertad y jurisdicción constitucional orgánica. En los primeros se encuentran aquellos procesos constitucionales que están destinados a proteger los derechos fundamentales, mientras que en los segundos, aquellos que buscan tutelar básicamente la jerarquía normativa de la norma constitucional. Léase al respecto la vasta obra de Mauro Cappelletti. Algunos de sus trabajos se encuentran, por cierto, traducidas al español. Así, por ejemplo, convendría revisar Cappelletti, Mauro. La jurisdicción constitucional de la libertad. Traducción de Héctor FixZamudio. México: Universidad Nacional Autónoma de México, 1996.

12 De acuerdo con lo establecido en el inciso 8 del artículo 5 de la ley 28237:

«No proceden los procesos constitucionales cuando:

[...]

8) Se cuestionen las resoluciones del Jurado Nacional de Elecciones en materia electoral, salvo cuando no sean de naturaleza jurisdiccional o cuando siendo jurisdiccionales violen la tutela procesal efectiva.

Tampoco procede contra las resoluciones de la Oficina Nacional de Procesos Electorales y del Registro Nacional de Identificación y Estado Civil si pueden ser revisadas por el Jurado Nacional de Elecciones;

[...]». 
Artículo 5o.- Causales de improcedencia.

No proceden los procesos constitucionales cuando:

[...]

8. Se cuestionen las resoluciones del Jurado Nacional de Elecciones en materias electorales, de referéndum o de otro tipo de consultas populares, bajo responsabilidad.

Resoluciones en contrario, de cualquier autoridad, no surten efecto legal alguno.

La materia electoral comprende los temas previstos en las leyes electorales y aquellos que conoce el Jurado Nacional de Elecciones en instancia definitiva.

No obstante lo señalado, debemos tomar en consideración que la modificación mencionada no solo contraviene lo dicho por el Tribunal Constitucional peruano, máximo intérprete de nuestra Constitución —el cual incluso en la coyuntura en la cual se debatía este tema en la institución parlamentaria, emitió una sentencia muy importante, en donde aborda nuevamente esta problemática e insiste en que las decisiones del Jurado Nacional de Elecciones pueden ser cuestionadas a través del amparo cuando vulneren la tutela procesal efectiva- ${ }^{13}$ sino que introduce y reconoce en el Perú espacios en donde los derechos fundamentales pueden verse seriamente amenazados o vulnerados, y los eventuales perjudicados no pueden plantear mecanismo procesal alguno de cara a obtener su tutela.

Sin lugar a dudas ya algunos autores, alegando la situación de indefensión que generaría asumir la postura del Jurado Nacional de Elecciones o poniendo de relieve la labor que le corresponde al Tribunal Constitucional en estos menesteres, en donde el control constitucional salta a la vista, se han ocupado del tema aquí descrito con bastante claridad y contundencia, ${ }^{14}$ por lo que, en principio,

13 Estamos haciendo referencia a la sentencia del Tribunal Constitucional peruano de fecha 8 de noviembre del 2005 recaída en el caso «Pedro Andrés Lizana Puelles» (expediente 58542005-PC/TC).

14 Puede revisarse sobre el particular ABAD YUPANQUI, Samuel. «El proceso de amparo en materia electoral: un instrumento para la tutela de los derechos fundamentales». En Elecciones, año 1, no 1. Lima: Jurado Nacional de Elecciones, noviembre 2002, p. 189 y ss.; ABAD YUPANQUI, Samuel. El proceso constitucional de amparo. Lima: Gaceta Jurídica, noviembre 2004, p. 419 y sS.; ESPINOSA-SAldaña BarRera, Eloy. "Órganos constitucionalmente autónomos y la pertinencia de una revisión de sus fallos en sede jurisdiccional peruana: algunos apuntes sobre el particular». En AA. VV. Derecho Procesal. I/ Congreso Internacional. Lima: Fondo de Desarrollo Editorial de la Universidad de Lima, 2002, p. 389 y ss., trabajo que se encuentra reproducido en su libro Jurisdicción constitucional, impartición de justicia y debido proceso. Lima: Ara Editores, 2003, p. 265 y ss.; Espinosa-Saldaña Barrera, Eloy. «¿Conviene que las decisiones del Jurado Nacional de Elecciones sean irrevisables por otra instancia jurisdiccional?». En Revista Peruana de Jurisprudencia, año 4, $\mathrm{n}^{\circ}$ 20. Trujillo: Editora Normas Legales, octubre 2002, p. xxxi y ss.; EsPINOSA-SALDAÑA BARRERA, Eloy. «Apuntes sobre la revisibilidad de las decisiones del Jurado Nacional de Elecciones peruano en materia electoral». En Revista Jurídica del Perú, año LV, no 65. Trujillo: Editora Normas Legales, 
podría resultar innecesario destinar más líneas sobre el particular. Sin embargo, el análisis que pretendemos realizar en esta oportunidad al respecto busca aproximar al lector a la misma problemática, pero desde una perspectiva que creemos, modestamente, distinta. En esta ocasión nuestro análisis se enmarca dentro de la teoría de los organismos constitucionalmente autónomos.

Indudablemente existen temas que al respecto convendría revisar, tales como la celeridad de los procesos que se lleven a cabo como consecuencia del cuestionamiento de una decisión del Jurado Nacional de Elecciones que, por ejemplo, declara como ganador de una contienda electoral a un determinado candidato en aras de asegurar la seguridad jurídica que se requiere en estos asuntos, ${ }^{15} \mathrm{o}$ el de si dicho cuestionamiento por medio del amparo pone o no en tela de juicio el carácter de máximo tribunal en lo electoral que se busca otorgar a dicho organismo constitucionalmente autónomo. ${ }^{16}$ Sin embargo, como adelantamos, en esta ocasión, intentaremos efectuar un breve análisis de este mismo problema, pero desde un enfoque diferente.

Somos de la opinión de que un planteamiento como el aprobado por el Congreso y que refleja la posición del Jurado Nacional de Elecciones, muy a despecho de la calidad personal y profesional de sus funcionarios y autoridades,

noviembre/diciembre 2005, p. 3 y ss.; Muguerza Guadalupe, Liliana. "La revisión de las decisiones del Consejo Nacional de la Magistratura y el Jurado Nacional de Elecciones por el Tribunal Constitucional peruano». En Espinosa-Saldaña Barrera, Eloy (coordinador). Derechos fundamentales y Derecho Procesal Constitucional. Lima: Jurista Editores, septiembre 2005, pp. 237 y ss.; entre otros.

15 Este ha sido un tema que el Tribunal Constitucional peruano también ha tenido presente. Las modificaciones a la ley 28237 que propone el Tribunal Constitucional peruano al Congreso de la República a efectos de atender de forma equilibrada este tipo de requerimientos son:

- Reducir sustancialmente el plazo de prescripción para interponer una demanda de amparo contra una resolución del Jurado Nacional de Elecciones en materia electoral.

- Que las demandas de amparo contra una decisión del Jurado Nacional de Elecciones en materia electoral sean presentadas ante la Sala Constitucional y Social de la Corte Suprema; y cuyas resoluciones denegatorias, emitidas en un plazo sumarísimo, puedan ser conocidas por el Tribunal Constitucional, mediante la interposición de un recurso de agravio constitucional a ser resuelto también en tiempo perentorio.

- Sancionar a aquellos jueces constitucionales que, contraviniendo el artículo 13 del Código Procesal Constitucional, no concedan trámite preferente a las demandas de amparo interpuestas contra las resoluciones del Jurado Nacional de Elecciones en materia electoral.

- Los plazos deben ser perentorios a efecto de no crear incertidumbre en las decisiones electorales y asegurar la confianza en el sistema de control jurisdiccional constitucional.

16 Aquí un tema de suma relevancia a dilucidar es el del organismo competente para conocer en primer y luego en segundo grado la demanda de amparo interpuesta. Al respecto, algunos autores, creemos con razón, han planteado que este asunto se vea, en primer grado, en la sede de la Sala Constitucional y Social de la Corte Suprema y, en segundo grado, en el Tribunal Constitucional. En este sentido encontramos a EsPINOSA-SALDAÑA BARRERA, Eloy. «Apuntes sobre la revisibilidad de las decisiones...». Ob. cit., p. 13. Ahora bien, en ese mismo entendimiento se encuentra, como vimos (revísese la parte final de la nota 15 de este texto), el Tribunal Constitucional peruano, tal como lo expresa en el caso «Pedro Andrés Lizana Puelles» (expediente 5854-2005-PA/TC). 
conduce a la consagración en el Perú de eventuales escenarios de ejercicio del poder estatal en condiciones de autarquía antes que de autonomía. Nadie discute que tanto el Jurado Nacional de Elecciones como el Tribunal Constitucional son organismos constitucionalmente autónomos, lo cual supone que ejercen la cuota de poder asignada bajo determinadas pautas y condiciones, distintas a las de cualquier otro organismo u órgano del Estado que se maneja en una lógica más bien de subordinación. Sin embargo, a nuestro juicio, ello no debe llevarnos a afirmar que dicha situación suponga que no puede haber mecanismos que los relacionen entre sí. Este último planteamiento, aprobado por el Congreso de la República y que el supremo intérprete de nuestra Constitución ha buscado dejar de lado, no se condice, como veremos, con lo que esboza la teoría general de los organismos constitucionalmente autónomos.

\section{Una mirada a la teoría general de los organismos constitucionalmente autónomos}

\subsection{Sobre el surgimiento de la noción de organismo constitucionalmente autónomo}

Si bien tradicionalmente se comprendía que un Estado estaba conformado por tres poderes - planteamiento que nos viene desde los tiempos en que Montesquieu escribió su famosa obra Del espiritu de las leyes, ${ }^{17}$ e incluso ya Aristóteles en su libro La política ${ }^{18}$ hacía una referencia a este tema-, hoy en

\footnotetext{
La especial insistencia que se hace en este tema, es decir, para que el supremo intérprete de nuestra Constitución conozca de estos menesteres en segundo grado y no en primero como planteaban algunos, se debe, entre otras cosas, a que va a ser el mismo texto constitucional peruano el que va a circunscribir su labor de tutela de los derechos fundamentales cuando conozca amparos, hábeas data, procesos de cumplimiento o hábeas corpus, a los supuestos en que lo resuelto en la judicatura ordinaria es desfavorable al demandante.

17 Así, según Montesquieu, «Hay en cada Estado tres clases de poderes: el poder legislativo, el poder ejecutivo de los asuntos que dependen del derecho de gentes y el poder ejecutivo de los que dependen del derecho civil.

Por el poder legislativo, el príncipe, o el magistrado, promulga leyes para cierto tiempo o para siempre, y enmienda o deroga las existentes. Por el segundo poder, dispone de la guerra y de la paz, envía o recibe embajadores, establece la seguridad, previene las invasiones. Por el tercero, castiga los delitos o juzga las diferencias entre particulares. Llamaremos a este poder judicial, y al otro, simplemente poder ejecutivo del Estado». En Del espíritu de las leyes I. Madrid: Sarpe, 1984, pp. 168-169.

18 En efecto, para Aristóteles: «En todo Estado hay tres partes que todo legislador prudente debe, en primer término, ordenar convenientemente. Una vez que se organizan estas tres partes, puede decirse que todo está bien organizado. El primero de estos elementos es la Asamblea General que delibera sobre asuntos públicos; el segundo, es el cuerpo de magistrados, cuya naturaleza, atribuciones y modo de designar es menester reglamentar; el tercero es el cuerpo judicial».
} 
día pese a que la Constitución peruana — creemos nosotros con poco rigor técnico y por lo tanto, equivocadamente- insiste en el mismo postulado, se admite que, en sentido estricto, el poder del Estado es uno que se divide en diferentes funciones cuyo ejercicio se confía más bien a diversos organismos $\mathrm{u}$ órganos en aras, eso sí, de evitar su concentración de tal forma que se abra la puerta al abuso o a su ejercicio anómico. ${ }^{19}$

En ese orden de ideas, el poder estatal es dividido más bien en un conjunto de funciones, las cuales por su importancia, complejidad, entre otros factores, son distribuidas a diferentes entidades para que, de acuerdo con la naturaleza de las tareas o labores que deben realizar, las ejerzan en condiciones sea de autonomía o de dependencia de otras instituciones, siendo estas últimas las responsables de cómo aquellas se llevan a cabo. Podría considerarse que estamos ante una consecuencia de la cada vez más evidente juridificación de la política o constitucionalización de la política, que responde al afán de consolidar el Estado constitucional y que supone, en términos generales, la configuración de las relaciones entre los componentes del aparato estatal como relaciones entre organismos $\mathrm{u}$ órganos dotados de competencias ${ }^{20}$ contempladas en el ordenamiento jurídico y susceptibles de ser sometidas a control en caso se ejerzan indebidamente.

De ahí que algunos autores sostengan que:

La noción de órgano constitucional se convierte así en equivalente de la de poder del Estado con el sentido de que los órganos constitucionales se identifican con los órganos del Estado a los que se atribuye el ejercicio, en condición de relativa independencia respecto a los otros, de funciones públicas en colaboración para actuar la voluntad del Estado. ${ }^{21}$

A lo dicho convendría añadir que la labor del Estado ha aumentado hoy en día, muy a pesar del rol subsidiario que se le atribuye en el aspecto económico, haciendo que la realización de las tareas consideradas como propias de él se hagan más complejas. Esto último va a traer como consecuencia, además, que algunas de aquellas tareas adquieran una importancia fundamental para atender las nuevas circunstancias a las cuales se debe hacer frente, por ejemplo, asegurar la vigencia de la norma suprema del Estado en un contexto en el que no cabe ninguna duda de que estamos ante una norma con innegable contenido

19 García Pelayo, Manuel. "El "status" del Tribunal Constitucional». En Revista Española de Derecho Constitucional, no 1. Madrid: Centro de Estudios Constitucionales, 1981, p. 20.

20 Gómez Montoro, Ángel J. El conflicto entre órganos constitucionales. Madrid: Centro de Estudios Constitucionales, 1992, p. 310.

21 Trujlllo Rincón, María Antonia. Los conflictos entre órganos constitucionales del Estado. Madrid: Publicaciones del Congreso de los Diputados, 1995, p. 42. 
político, pero también y hoy sobre todo, norma jurídica, ${ }^{22}$ y en el que existe una proliferación de organismos u órganos con potestad legislativa tanto a nivel en el ámbito interno como externo. La tutela de los derechos fundamentales frente a escenarios que traen consigo nuevas formas de eventuales atentados contra ellos, por mencionar tan solo algunos de los supuestos quizá más notorios, constituye también parte de la actual agenda de todo Estado constitucional que se precie de serlo.

La noción de organismo constitucionalmente autónomo pareciera entonces deber su origen, justamente, a la necesidad de explicar la naturaleza de esos nuevos elementos que obligan a contar con organismos específicos para tal efecto y que, a pesar de ser esenciales en la estructura del Estado, no encajan en la concepción tradicional de la división tripartita del poder estatal. En términos de García Pelayo ${ }^{23}$ "[...] los conceptos de órgano constitucional y sus fines responden a la necesidad inherente a cualquier organización de cierta amplitud y complejidad —y por tanto al Estado- de jerarquizar sus unidades y subunidades de decisión y acción, es decir, sus órganos».

Lo señalado precedentemente explica cómo es que, por ejemplo en el Perú, además de los equívocamente denominados Poder Ejecutivo, Poder Legislativo y Poder Judicial, contamos con entidades cuya labor es de tal envergadura que no solo cuentan con autonomía reconocida expresamente en el texto constitucional, sino que será la misma Constitución la que precise, en líneas generales, las atribuciones que ostentan, cómo se nombran a los funcionarios que las representan, entre otros temas de indudable relevancia para asegurarle condiciones precisamente de autonomía para el ejercicio de la importante cuota de poder depositada en cada una de ellas.

\subsection{Hacia una definición de organismo constitucionalmente autónomo}

La elaboración de la idea a la cual venimos haciendo referencia se la debemos sin duda alguna a Romano. ${ }^{24}$ Sin embargo, él construyó su concepto de organismos constitucionalmente autónomos - $\mathrm{u}$ órganos constitucionales como

22 Sobre el carácter normativo de la Constitución convendría revisar, entre otros interesantes trabajos, el ya conocido libro de García de EnTERría, Eduardo. La Constitución como norma y el Tribunal Constitucional. Tercera edición. Madrid: Editorial Civitas, 1985, especialmente p. 49 y ss.

23 García Pelayo, Manuel. «El "status" del...». Ob. cit., p. 12.

24 Se conviene, pues, en sostener que Romano es quien en su trabajo intitulado Nozione e natura degli organi costituzionali dello Stato del año 1898, luego de descartar algunos criterios propuestos para sustentar la diferencia entre los Ilamados órganos constitucionales y los órganos administrativos, intentara darnos una definición de lo que debemos entender por los primeros. Así, Romano rechaza, por ejemplo, que un elemento diferenciador entre los denominados órganos constitucionales y los administrativos sea que aquellos son los que integran el objeto del derecho constitucional. Asimismo, tampoco comparte el criterio de 
les llama- luego de revisar las construcciones ya esbozadas en su momento por autores como Gierke o Jellinek. En efecto, estos últimos distinguían entre órganos estatales inmediatos (unmittelbaren Staatsorganen) y mediatos (mittelbaren). Gierke definía a los primeros, en contraposición a los segundos, como aquellos que no dependen ni están subordinados a ningún otro órgano. Jellinek, por su parte, nos dirá que los órganos inmediatos son aquellos cuya existencia es lo que determina la formación de las asociaciones, y cuya desaparición desorganiza completamente al Estado o lo transforma fundamentalmente. Asimismo, añadiría a su definición, que la propia naturaleza de los denominados órganos inmediatos obliga a que no puedan estar jamás sometidos al poder de mando de otro órgano — nosotros preferiríamos hablar de organismo- ${ }^{25}$

que lo que distingue a ambas nociones, es que los órganos constitucionales participan de forma inmediata de la soberanía.

Finalmente, Romano sostendrá que un criterio válido para establecer dicha diferenciación es la "posición que el órgano mismo asume frente al Estado», y nos dirá, en esa línea de pensamiento que «[...] los órganos constitucionales del Estado; son aquéllos que son necesarios para individualizar a este último en un determinado momento histórico, para darle una efectiva existencia, para reducirlo de una abstracción simple a un ente vital y capaz de seguir organizándose para la consecución de sus fines».

Añade que «[...] constitucionales son aquellos órganos a los que es confiada la actividad directa del Estado y que gozan, en los límites del derecho objetivo que los coordina entre sí, pero que no subordina uno a otro, de una completa independencia recíproca». Véase: GómEz Montoro, Ángel J. «El conflicto entre...». Ob. cit., pp. 312-313.

$25 \mathrm{Y}$ es que con la expresión «organismo» se alude a aquella entidad del Estado que debe su existencia a la Constitución o a la ley, a la cual se le ha confiado la realización de una actividad o de varias conexas entre sí en términos de autonomía, y cuya regulación deriva del derecho público. En ese orden de ideas, entran en la calificación de "organismo», tanto los denominados organismos constitucionales, como, por ejemplo, los organismos públicos descentralizados.

Ahora bien, con el término "órgano», se hace referencia más bien a toda aquella dependencia o repartición de un organismo, por lo que no goza de autonomía, y que tiene como función el desarrollo de una actividad determinada bajo el mando de una autoridad administrativa. Dicha función puede ser, por ejemplo, la resolución de conflictos o gestión al interior del organismo. Ejemplo de órganos pueden ser las direcciones al interior de un ministerio en particular. Recomendamos revisar Cosculluela Montaner, Luis. Manual de Derecho Administrativo. Madrid: Civitas, 1993, p. 172 y ss.

Para Jellinek, pues, «En todo Estado existen necesariamente órganos inmediatos cuya existencia es lo que determina la forma de las asociaciones, y cuya desaparición o desorganiza completamente al Estado, o lo transforma fundamentalmente. Tales órganos se Ilaman inmediatos, porque su carácter de órganos es una consecuencia inmediata de la constitución de la asociación misma. Es decir, de cualquier suerte que se establezcan estas asociaciones, estos órganos no están obligados, en virtud de su cualidad de tal, hacia nadie, sino sólo y de un modo inmediato con respecto al Estado mismo. Su situación radica en la organización de la propia asociación, a tal punto que, sólo mediante ellos, puede la asociación advenir activa». JeLlinek, Georg. Teoría general del Estado. Prólogo y traducción de Fernando de los Ríos. México: Fondo de Cultura Económica, 2000, pp. 488-489. Y nos dice que «órganos mediatos» son «[...] aquellos cuya situación no descansa de modo inmediato en la Constitución, sino en una comisión individual. Son responsables y están subordinadas a un órgano inmediato, directa o indirectamente. Su actividad respecto a la colectividad es siempre derivada». Ibíd., pp. 498-499. 
De esa esta manera, tanto Gierke como Jellinek ponen de relieve la autonomía como un elemento característico y esencial de lo que llaman órganos inmediatos y que se aproxima a la noción de organismo constitucionalmente autónomo. Sin embargo, de ningún modo, como indicaremos con posterioridad, debe confundirse esa pregonada autonomía con un escenario de autarquía.

Luego de la formulación de Romano, algunos autore ${ }^{26}$ se han preocupado por definir con mayor rigor lo que debe entenderse por organismo constitucionalmente autónomo, y es que estamos ante un concepto que no está libre de una serie de elementos que dificultan su precisión, con la consecuente complejidad para determinar con claridad cuándo estamos ante un organismo constitucionalmente autónomo y cuándo más bien ante un organismo u órgano de relevancia constitucional, o un simple órgano estatal. De ahí que se hayan planteado también algunos criterios y vías de cara a precisar la presencia de un organismo constitucionalmente autónomo. ${ }^{27}$

Independientemente de ello, la doctrina mayoritaria parece inclinarse por considerar que se trata de organismos a los cuales se les ha confiado la actividad directa e inmediata del Estado, y que, en los límites del derecho objetivo, que los relaciona entre sí, pero no los subordina unos a otros, gozan de autonomía

26 Otros autores como Mazziotti intentarán, por ejemplo, definir a los organismos constitucionalmente autónomos como «[...] una organización parcial —ufficio o complesso di uffici del Estado - caracterizada sobre todo por la competencia para ejercer en grado supremo un complejo de funciones públicas, y en segundo lugar por la idoneidad para frenar, controlar y equilibrar a los otros órganos dotados de competencias similares; constituida por ello en el ordenamiento en una posición de relativa independencia y paridad respecto a estos órganos». Citado por Gómez Montoro, Ángel J. «El conflicto entre...». Ob. cit., p. 317. Manuel García Pelayo, por su parte, nos dice que los organismos constitucionalmente autónomos «[...] no pueden ser otros que aquellos que reciben directamente de la Constitución su status y competencias esenciales a través de cuyo ejercicio se actualiza el orden jurídico político fundamental proyectado por la misma Constitución». En «El "status" del Tribunal Constitucional...». Ob. cit., p. 13.

27 Con mayor detalle puede verse Gómez Montoro, Ángel J. «El conflicto entre...», ob. cit., pp. 317-319. Ahora bien, los ordenamientos jurídicos comparados suelen acudir a dos vías para determinar cuándo estamos ante un organismo constitucionalmente autónomo (ob. cit., pp. 321-322). Una de ellas es aquella que deja a la normativa de desarrollo constitucional la precisión de este tipo de cuestiones. Esta vía es cuestionada por el amplio margen de libertad que se puede dejar en manos del legislador, no solo para regular temas relevantes como es el de la composición de estos organismos constitucionalmente autónomos, así como sus atribuciones, sino, y lo que puede ser peor, queda en decisión del legislador el determinar el nivel de autonomía de estos organismos constitucionalmente autónomos.

Una segunda vía es aquella en la que es el mismo texto constitucional el que se encarga de determinarlos. Y para tal efecto, se entra a revisar en la Constitución los organismos que cumplen con los requisitos de estar configurados directamente por ella y tener garantizada la autonomía que les es propia. Lo que se entra a cuestionar en esta última fórmula, es que puede ocurrir que un texto constitucional consagre como organismos constitucionalmente autónomos, entidades que no suele ser consideradas como tales, o no enumere las competencias o no incluya las disposiciones relativas a la autonomía de aquellos organismos que sí son considerados generalmente como constitucionales. 
y paridad recíproca. Se trata, asimismo, de entidades que se encuentran en el vértice de la organización estatal, que no tienen superiores y son sustancialmente iguales entre sí. Convendría, eso sí, poner de relieve, especialmente para los fines de este trabajo, que si bien gozan de autonomía, ello no supone el reconocimiento de espacios autárquicos, es decir, sin mecanismos de relación entre sí. $^{28}$ Como ya habíamos precisado, no es lo mismo hablar de autonomía que de autarquía. ${ }^{29}$

Necesario es también precisar, tal como lo habíamos advertido algunas líneas atrás, que no es lo mismo hacer referencia a un organismo constitucionalmente autónomo, que a un organismo u órgano de relevancia constitucional. Estamos ante dos categorías que, aun cuando suelen confundirse, son en rigor, distintas.

Así, según sostiene un sector de la doctrina, los denominados organismos u órganos de relevancia constitucional son aquellos contemplados directamente en la Constitución, por lo que son destinatarios de una garantía institucional amparada por la norma suprema del Estado, pero que son órganos coadyuvantes de los organismos constitucionalmente autónomos. En otras palabras, no es que sean auxiliares de estos últimos, sino que son instituidos para el ejercicio independiente de las competencias a ellos atribuidas respecto de cierta función estatal, lo que no impide que se relacionen más estrecha y frecuentemente con

28 Aquí hacemos hecho nuestra, en términos generales, la definición que esboza TrujILLO RINCón, María Antonia. "Los conflictos entre...». Ob. cit., pp. 41-42. Es menester precisar, eso sí, que la autora mencionada agrega a su concepto de organismo constitucionalmente autónomo, que este no puede ser sometido a control jurisdiccional o análogo. Aquí sí hemos de manifestar, muy respetuosamente, nuestra discrepancia con dicha afirmación, puesto que somos de la opinión que el control del ejercicio de las funciones atribuidas a dichos organismos por parte de una entidad con fisonomía jurisdiccional, como puede ser la judicatura ordinaria o el Tribunal Constitucional, no rompe con la autonomía característica de este tipo de instituciones. Por el contrario, es nada más y nada menos, un espacio que permite (y busca) controlar el ejercicio del poder estatal bajo pautas jurídicas, lo cual es propio de un Estado constitucional, y que pasa a formar parte de los diversos mecanismos de relación que deben existir entre los diferentes organismos constitucionalmente autónomos, salvo mejor parecer.

29 Se afirma, pues, que un organismo del Estado será un organismo constitucionalmente autónomo cuando (ibíd., p. 45):

a) Sea un elemento necesario del ordenamiento jurídico, en el sentido de que si faltara se detendría la actividad del Estado o se produciría la ilegítima transformación de este.

b) Sea un elemento indefectible en el sentido de no caber situación alguna por parte de otros organismos constitucionales, sin un cambio de régimen político.

c) Reciba ipso iure de la Constitución todos los atributos fundamentales de su condición y posición de organismo, contando con una estructura de base dictada enteramente por la Constitución, es decir, encuadrándose en la separación coordinada de los poderes supremos del Estado y en el sistema del equilibrio constitucional.

d) Esté, como consecuencia, en posición de paridad e independencia respecto a los otros organismos constitucionales, es decir, ni sea autárquico ni esté jerárquicamente subordinado, sino que sean superiores non recognocens. 
la actividad de un determinado organismo constitucionalmente autónomo que con la de otro. ${ }^{30}$

\subsection{Algunos de los rasgos más relevantes de los organismos constitucionalmente autónomos}

Por otro lado, los organismos constitucionalmente autónomos se caracterizan fundamentalmente porque gozan de configuración directa e inmediata por la Constitución, participan en la dirección política del Estado, son constitutivos del modelo de Estado asumido en un ordenamiento dado y pertenecen al mismo rango jurídico político. Veamos con más detalle qué supone cada uno de los rasgos a los cuales acabamos de hacer mención. ${ }^{31}$

Cuando se afirma que los organismos constitucionalmente autónomos gozan de directa e inmediata configuración por parte del texto constitucional, quiere decir que son establecidos y determinados en sus aspectos esenciales y fundamentales por la misma Constitución. En otros términos, la Carta Magna no se limita sencillamente a mencionarlos ni a enumerar tan solo sus atribuciones, funciones o competencias que es, como vimos, lo que pasa con los denominados organismos u órganos de relevancia constitucional, sino que va más allá de eso y precisa otros temas de mayor envergadura en torno a su configuración. En ese orden de ideas, materias como las de su composición, los organismos y métodos que conducen al nombramiento de sus miembros, su estatus institucional, entre otras, son las que se encuentran claramente determinadas en la norma fundamental, lo cual es lógica consecuencia, como ya habíamos indicado, de la importancia que adquieren estos organismos para el cumplimiento de las tareas estatales.

Se afirma también, en la línea incluso de lo recientemente señalado, que los organismos constitucionalmente autónomos se caracterizan por participar activamente en la dirección política del Estado, esto es, tienen una cuota de injerencia en la formación de la voluntad estatal, en la dirección del Estado, en buena cuenta, en lo que en doctrina italiana se conoce como indirizzo politico, que consiste en traducir los fines políticos en formulaciones jurídicas. ${ }^{32} \mathrm{Sin}$ embargo, esto no debe llevarnos a pensar que la labor del Tribunal Constitucional, que sin lugar a dudas es un organismo constitucionalmente autónomo, es de corte político, es decir, adopta decisiones políticas. Como veremos con más detalle luego, el supremo intérprete de la norma constitucional realiza un

\footnotetext{
Ibíd., pp. 46-49.

31 Para el desarrollo de este apartado nos hemos servido fundamentalmente del trabajo ya aquí citado de García Pelayo, Manuel. «El "status" del...». Ob. cit., p. 13 y ss.

32 Gómez Montoro, Ángel J. «El conflicto entre...». Ob. cit., p. 315.
} 
control jurídico, no político. Por consiguiente, toma decisiones bajo parámetros jurídicos, lo cual no evita a que ellas traigan consecuencias políticas, o que incluso los conflictos que dicho Alto Tribunal resuelve tengan un sustrato político.

Otra de las características que identificarían a un organismo constitucionalmente autónomo, es que son reputados como constitutivos del modelo de Estado asumido en un ordenamiento dado. Son calificados como troncales para la configuración del modo de ser y existir de un ordenamiento constitucional determinado, de tal forma que, como decía Jellinek, su desaparición traería como consecuencia una desorganización del aparato estatal o su transformación fundamental.

Por último, se sostiene que todos aquellos organismos a los cuales se considere como constitucionalmente autónomos, ostentan el mismo rango jurídico político. Esto quiere decir que ninguno de ellos es una parte integrante, dependencia u órgano de otro organismo, por el contrario, cada uno es supremo in suo ordine. En otros términos, quizá más sencillos y aunque resulte redundante, son autónomos en el ejercicio de las atribuciones que se les ha confiado, y entre las que se comprende el establecimiento de su propia organización (autorregulación).

Lo recientemente señalado - y disculpará el lector si hacemos demasiada incidencia en este tema, pero lo cierto es que es el punto central de este trabajo-, no debe conducirnos a afirmar que si un organismo constitucionalmente autónomo lleva a cabo de forma incorrecta las funciones que se le han atribuido, no hay mecanismo alguno que permita corregir dicha situación o incluso determinar responsabilidades ulteriores. De permitirse este tipo de esquemas en un ordenamiento jurídico, no estaríamos respetando la distribución de competencias previamente determinada y admitiríamos espacios de autarquía que rompen con el concepto de autonomía que es propio de este tipo de organismos. Como veremos, la postura del Jurado Nacional de Elecciones, plasmada en la modificación introducida por el Congreso de la República al Código Procesal Constitucional, conduce nada más y nada menos que a este tipo de escenarios.

Y es que, por más autonomía que se pregone respecto de estos organismos constitucionales, lo cierto es que no solo deben haber mecanismos que les permitan relacionarse entre sí, de tal forma que la decisión adoptada por alguno de ellos incida de alguna u otra manera en la de otro, sino que jamás debe dejarse de lado la posibilidad de que alguno de estos organismos puede excederse en el ejercicio de sus funciones o cuando las lleve a práctica, lesionar derechos fundamentales; $y$ por lo tanto, es menester asegurar mecanismos que permitan, siguiendo el orden de competencias establecido en la Constitución, corregir este tipo de situaciones. En otras palabras, el control y la limitación del poder como pauta propia de un Estado constitucional se erige en estos 
menesteres como un elemento esencial para asegurar así un adecuado ejercicio del poder estatal.

En esa línea de pensamiento, veremos a continuación los tipos de relaciones que debieran presentarse entre los organismos constitucionalmente autónomos. Convendría precisar, eso sí, que esta necesaria relación debe llevarse a cabo de acuerdo con el marco constitucional establecido y la distribución de competencias allí consignada. Así, por ejemplo, como trataremos luego con más detalle, queda claro que si estamos ante un organismo constitucionalmente autónomo cuyo accionar lesiona un derecho fundamental o invade el ámbito de actuación de otra entidad estatal de su mismo rango jurídico político, la institución que se pronunciará será tanto la judicatura ordinaria, en los asuntos que le compete, como el Tribunal Constitucional, en las materias que le son propias, y esto no supone, de ninguna manera, pasar por encima de la autonomía de aquel organismo que presuntamente ha hecho un indebido ejercicio de la cuota de poder que se le confió. Insistimos, contar con autonomía no es lo mismo que gozar de autarquía.

\subsection{La necesaria interacción entre los organismos constitucionalmente autónomos: los tipos de relaciones que existen $-\mathrm{o}$ al menos debieran presentarse- entre ellos}

Se afirma que básicamente son dos los tipos de relaciones que existen entre los organismos constitucionalmente autónomos, sin perjuicio de otros que no conviene detallar aquí. Estamos haciendo referencia al conflicto competencial $\mathrm{y}$ al control.

Cuando hablamos de conflicto competencial, aludimos a aquella discrepancia de corte jurídico que surge entre dos organismos como consecuencia del no respeto del régimen de distribución de competencias consagrado en el ordenamiento jurídico de un Estado, que en el caso de los organismos constitucionalmente autónomos se encuentra fundamentalmente en la Constitución. En caso surja alguno de estos conflictos, se acudiría al procedimiento establecido con anterioridad y positivamente para exigir su solución.

Suelen presentarse dos tipos de conflictos de competencia: el positivo y el negativo. El conflicto positivo de competencia es el escenario más frecuente y se manifiesta cuando dos o más organismos recíprocamente afirman ser competentes para asumir la realización de una tarea o labor concreta. En estos casos

[...] los órganos reivindican la competencia para realizar un determinado acto como propio, negando cada uno de ellos que la potestad de emanar ese acto esté dentro de la esfera de atribuciones del otro, de forma que al ejercitar uno de ellos esa potestad atribuida por las normas positivas a otro, está violando esas 
normas, superando los límites competenciales regulados y usurpando la potestad de otro. Uno de los órganos considera el comportamiento del otro ilegítimo, al violar las reglas competenciales, y lesivo, al invadir la propia esfera de atribuciones. ${ }^{33}$

Por su parte, el conflicto negativo de competencia consiste en aquel escenario en el cual los organismos involucrados niegan su potestad para ejercer una función en el caso planteado, pues asumen que dicha situación no se encuentra en la esfera de competencias que se les ha atribuido, sino en la de otro. Este tipo de conflicto competencial puede presentarse sea porque un organismo aduce ser incompetente para actuar en un determinado asunto y otro repute tal conducta como ilegítima, sea porque ambos organismos sostengan que aquel no es competente sino el otro. ${ }^{34}$

Un tercer supuesto esbozado por un sector de la doctrina, es el denominado como amenaza de conflicto competencial y definido como:

[...] la amenaza producida al violar un órgano los límites competenciales señalados a otro, pero de forma que el ejercicio de esta potestad no determina una invasión de la esfera competencial, sino que el ilegítimo comportamiento de ese órgano le lesiona al no poder desarrollar una función propia o sólo realizarla parcialmente, viéndose frustrada o disminuida su actividad. ${ }^{35}$

Ahora bien, otro tipo de relación que existe entre los organismos constitucionalmente autónomos, y sobre el cual quisiéramos hacer especial incidencia, es el del control, y en este caso obviamente estamos haciendo referencia a un tipo de control interórgano. ${ }^{36}$

Acerca de lo que debe entenderse por control se han planteado diversas teorías. ${ }^{37}$ Algunas de ellas hacen especial referencia a la sanción como un elemento imprescindible de él, mientras que otras consideran que esta, sin perjuicio de

\footnotetext{
TRUנILLo Rincón, María Antonia. «Los conflictos entre...». Ob. cit., p. 60.

Ibíd., p. 61.

35 En este tenor, ibíd., loc. cit.

36 Se hace referencia a controles intraórganos, cuando las instituciones de control operan al interior de la organización de una misma entidad. Así, por ejemplo, la Oficina de Control de la Magistratura realiza un control de tipo intraórgano, pues se encuentra al interior del mismo aparato de la judicatura ordinaria y vela por el régimen disciplinario de nuestros jueces. Por otro lado, hablamos de controles interórganos, cuando las instituciones de control operan, más bien, entre diversos detentadores del poder, como ocurre en este caso, o, por ejemplo, en el supuesto de los mecanismos de control político que ostenta el Congreso de la República frente a la actuación del Gobierno. En esa línea de pensamiento, el voto de censura, la interpelación, por citar tan solo algunos de ellos, son claramente mecanismos de control interorgánico. Puede verse para mayor detalle sobre el particular: LoEWENSTEIN, Karl. Teoría de la Constitución. Barcelona: Editorial Ariel, 1975, p. 232 y ss.

37 Así, por ejemplo, la doctrina italiana sostiene que el control es un fenómeno complejo integrado por dos elementos, que son: la actividad dirigida a establecer si la conducta del
} 
ser una pauta importante, no es esencial del concepto de control. Así, podríamos considerar que el control viene a ser la actividad de un sujeto, organismo u órgano, que llamaremos controlante, destinada a verificar o comprobar si la conducta, comportamiento o el ejercicio de funciones realizada por otro sujeto, organismo u órgano, que podríamos denominar controlado, se ajusta o no a los parámetros establecidos para su ejecución, actividad de la cual podrá, eventualmente, derivarse una sanción. ${ }^{38}$

En torno al control, y para efectos de los fines de este trabajo, es menester distinguir entre el control jurídico y el control político. Y es que es muy distinto el margen de acción que ostenta un organismo cuando realiza un control de corte político, como es por ejemplo el que efectúa el Congreso de la República respecto de la gestión de los ministros de Estado; que con el que cuenta un organismo que realiza un control jurídico, el cual es, por ejemplo, el que está en manos del Tribunal Constitucional o la judicatura ordinaria.

Como pautas esenciales que diferencian un tipo de control del otro están, entre otras, el carácter objetivo del control jurídico, en tanto se ciñe a parámetros jurídicos previamente establecidos y susceptibles de comprobación, frente al carácter subjetivo del control político, pues se sustenta en razones de calidad u oportunidad, no existiendo un canon fijo y predeterminado de valoración que regule la conducta del organismo controlante.

oganismo, órgano o sujeto controlado se ajusta o no a las pautas en torno a las cuales se produce la actividad de control y, en segundo término, el comportamiento a través del cual el organismo, órgano o sujeto controlante evita que el controlado continúe realizando aquella actividad disconforme a los parámetros del control y, eventualmente, por consiguiente, impone la sanción correspondiente, siendo este segundo momento el considerado como esencial.

Si para esta postura la sanción pasa a ser un elemento clave en la definición de una actividad como de control, en consecuencia, en caso un organismo, órgano o sujeto evalúe la conducta del controlado sobre la base de ciertas pautas, pero no ostenta la facultad de imponerle sanción alguna o de impedirle la continuación de la conducta que no se ajusta a aquellas pautas, no estaríamos ante un supuesto de control.

Otro sector es de la opinión, más bien, que lo relevante es el primer momento, es decir, el examen respecto de si la conducta efectuada por el controlado responde o no a los parámetros establecidos, muy a despecho de si se le impone o no luego una sanción.

En todo caso, independientemente de las diversas posturas existentes sobre el particular, podemos reconocer la presencia de tres elementos en una actividad de control. El primero es la materia que va a ser objeto de control, que vendría a ser la producción por parte de un organismo, órgano o sujeto de una actividad o conducta que luego va a ser sometida a la evaluación correspondiente. Dicho examen se realiza sobre la base de una serie de pautas o parámetros previamente establecidos, los cuales configuran el segundo elemento a tomar en cuenta. Por último, tenemos el acto de comparar la actividad o conducta efectuada por el controlado con las pautas previamente fijadas. Luego, de dicha comparación, e independientemente de la actividad de control ya realizada, podrán eventualmente derivarse una serie de consecuencias respecto del controlado, sea de sanción o con miras a evitar que continúe realizando aquel comportamiento. Véase al respecto: Trujıllo Rincón, María Antonia. «Los conflictos entre...». Ob. cit., p. 54.

38 Ibíd., p. 55. 
Otro elemento diferenciador es que el control jurídico se realiza de forma necesaria, no existiendo margen de dubitación ni discrecionalidad alguna para el sujeto, organismo u órgano encargado de llevar a cabo dicho control. Si un sujeto comete una conducta delictiva, un juez o magistrado no entra a evaluar si es realmente oportuno o conveniente condenar al responsable, sencillamente debe aplicar la normatividad penal vigente. Sin embargo, en el caso del control político, sí existe ese margen de dubitación. En esa línea de pensamiento, el Congreso de la República podría entrar a evaluar, en un contexto de grave crisis política, la conveniencia de censurar o no a un ministro de Estado por una discutible gestión de su despacho.

\section{El escenario actual: entre la autarquía y la necesaria presencia de un control y limitación del poder para la vigencia de un Estado constitucional}

Ahora bien, una vez que hemos dado un marco teórico general en torno a los organismos constitucionalmente autónomos, es menester trasladar aquel esquema conceptual a la actual coyuntura por la que viene atravesando nuestro país, esto es, si deben o no revisarse las decisiones del Jurado Nacional de Elecciones cuando contravienen la Constitución, en particular cuando lesionan la tutela procesal efectiva, según prescribe el Código Procesal Constitucional, tarea que correspondería en última instancia al Tribunal Constitucional.

Como bien habrá podido inferir el lector de lo descrito hasta este momento, ambos organismos - tanto el Jurado Nacional de Elecciones como el Tribunal Constitucional — son nada más y nada menos que organismos constitucionalmente autónomos, lo cual supone, tal como ya se señaló en este texto, que estamos ante entidades que gozan, entre sus rasgos más relevantes y sobre el cual queremos hacer especial incidencia, de un margen de acción en términos de autonomía respecto de los demás organismos del aparato estatal, pero que no debe confundirse con autarquía.

En efecto, como regla general, los tribunales electorales se encuentran configurados como organismos autónomos de los tres poderes tradicionales. ${ }^{39}$ Así, en Latinoamérica conviene destacar el caso de Nicaragua que consagra

39 En el caso de los tribunales electorales se afirma pues que «[...] hoy en día todos los países latinoamericanos poseen un órgano estatal encargado de las funciones electorales, el cual se encuentra situado en la mayoría de los casos al margen de los tres poderes públicos tradicionales - por lo cual muchos autores tienden a calificarlos como cuarto poder del Estado-, mientras que en dos países (Argentina y Brasil) está integrado al Poder Judicial». Jaramillo, Juan. «Los órganos electorales supremos». En Nohlen, Dieter, Picado, Sonia y Zovatto, Daniel (compiladores). Tratado de derecho electoral comparado en América Latina. México: Fondo de Cultura Económica, 1998, p. 206. 
expresamente en su texto constitucional la presencia de un poder electoral. En Costa Rica, la norma fundamental reconoce la autonomía del Tribunal Supremo de Elecciones respecto de los denominados poderes del Estado. Y resultan más bien excepcionales los casos que se presentan en países como Brasil, Argentina, México y Paraguay, en donde el tribunal electoral está considerado al interior de la organización de la judicatura ordinaria o conocida equívocamente como "Poder Judicial». ${ }^{40}$

En el caso peruano cabe destacar la Constitución de 1933, que, luego del oncenio de Leguía, en un afán de configurar una organización electoral encabezada por un organismo autónomo, con decisiones que eran en principio inimpugnables, consagró, creemos con poca rigurosidad técnica, la presencia de un «Poder Electoral». Hoy en día, el texto constitucional peruano vigente, en su artículo 177, pone de relieve la autonomía de los organismos que conforman el denominado sistema electoral ${ }^{41}$ peruano. ${ }^{42}$

En cuanto al Tribunal Constitucional, que resulta propio del modelo de control de constitucionalidad concentrado, también encontramos que, dentro de las diversas fórmulas existentes en América Latina en torno a la jurisdicción constitucional, ${ }^{43}$ los países que lo han previsto han tratado de revestirlo de

40 Orozco Henríquez, Jesús. «El contencioso electoral/la calificación electoral». En Nohlen, Dieter, Picado, Sonia y Zovatto, Daniel (compiladores). Ob. cit., p. 741.

${ }^{41}$ Convendría resaltar la mala utilización que se presenta en la Constitución de 1993 respecto de la expresión sistema electoral. Y es que en rigor, en doctrina y tal como lo demuestra la experiencia comparada, se entiende por sistema electoral, desde el punto de vista técnico, al modo a través del cual el elector expresa, por medio del voto, el partido o el candidato de su preferencia, y cómo esos votos pasan a convertirse en escaños o representaciones electas. En ese orden de ideas, los temas que comprende un sistema electoral son el establecimiento de la distribución de las circunscripciones, de la forma de la candidatura, de los procesos de votación y de los métodos de conversión de votos en escaños, entre los cuales se encuentra el Hare, D’Hont, Saincte-Lague o Cifra Repartidora. Recomendamos revisar NoHLEN, Dieter. Sistemas electorales y partidos políticos. Segunda edición. México: Fondo de Cultura Económica, 1998, específicamente p. 35.

42 Hacemos referencia al Jurado Nacional de Elecciones, la Oficina Nacional de Procesos Electorales y el Registro Nacional de Identificación y Estado Civil.

43 En Latinoamérica, se identifican básicamente las siguientes fórmulas en cuanto a la configuración del control de constitucionalidad. Hay países como Bolivia y Colombia en donde la labor del control de constitucionalidad se confía a tribunales o cortes autónomos dentro de la propia estructura de la judicatura ordinaria. En casos como los de Costa Rica, El Salvador, Nicaragua, Paraguay y Venezuela dicha tarea la realizan, más bien, salas especializadas en materia constitucional pertenecientes a las propias cortes o tribunales supremos. En Argentina, Brasil, Honduras, México, Panamá y Uruguay el control de constitucionalidad es Ilevado a cabo por cortes o tribunales supremos ordinarios que realizan funciones de tribunal constitucional, aunque no de manera exclusiva. Y, por último, tenemos el caso de Chile, Ecuador, Guatemala y Perú en donde son tribunales o cortes constitucionales autónomos ubicados fuera del aparato jurisdiccional ordinario los que realizan tan delicada labor. Véase al respecto FerRer MAC-GREGor, Eduardo. Los tribunales constitucionales en Iberoamérica. México: Fundap, 2002, pp. 27-28; García Belaunde, Domingo. De la jurisdicción constitucional al Derecho Procesal Constitucional. Cuarta edición. Lima: Editora Jurídica Grijley, 
aquella pregonada autonomía constitucional en aras de garantizarle condiciones adecuadas para el ejercicio de las importantes funciones que se le confían. ${ }^{44}$

A lo dicho hasta aquí convendría añadir que, por ejemplo, en nuestro país es el mismo texto constitucional el que determina la configuración básica de ambos organismos. En ese orden de ideas, el artículo 179 de la Constitución peruana precisa la composición del Pleno del Jurado Nacional de Elecciones, en su calidad de máxima autoridad de dicha institución, y el 180, los requisitos que deben cumplir sus integrantes. El artículo 201 hace lo propio respecto del Tribunal Constitucional. Las funciones básicas del Jurado están recogidas en el artículo 178, mientras que las del supremo intérprete de nuestra Constitución se encuentran en el artículo 202.

La incidencia en la dirección política del Estado que tienen las decisiones de un organismo con fisonomía jurisdiccional como es el caso del Jurado Nacional de Elecciones y el Tribunal Constitucional han sido explicadas anteriormente. Recuérdese que habíamos dicho que ello no debe llevarnos a asumir que dichas entidades adoptan decisiones políticas, sino que los efectos de dichas decisiones pueden ser políticos o, en todo caso, que detrás de un conflicto o situación de incertidumbre con relevancia jurídica que se presenta ante el Jurado Nacional de Elecciones o ante el Tribunal Constitucional, puede encontrarse una controversia política o con implicancias políticas.

En efecto, así se sostiene respecto del Tribunal Constitucional que:

[...] las demandas planteadas ante el Tribunal son en muchas ocasiones [...] la formulación en términos de litis jurídica de cuestiones o conflictos políticos, lo que tiene como consecuencia que sus decisiones, aún orientadas y fundamentadas en parámetros y valores jurídicos, tengan una significación y unos efectos no sólo para el ejercicio de las actividades políticas del Estado, sino también (en un Estado de partidos, como necesariamente lo es el Estado democrático de nuestro tiempo) respecto a las posiciones de los partidos o agrupaciones de partidos. Para poner el ejemplo más manifiesto: si cincuenta diputados o senadores del

2003, pp. 64-65; Eguiguren Prael, Francisco. Los tribunales constitucionales en Latinoamérica: una visión comparativa. Buenos Aires: CIEDLA, 2000; entre otros, y con mayor precisión respecto de cada país García Belaunde, Domingo y Fernández Segado, Francisco (coordinadores). La jurisdicción constitucional en Iberoamérica. Madrid: Dykinson, 1997; así como LösıNG, Norbet. La jurisdiccionalidad constitucional en Latinoamérica. Madrid: Dykinson y Fundación Konrad Adenauer, 2002.

44 Kelsen, al momento de desarrollar su modelo de control de constitucionalidad, precisó la autonomía de la cual debía gozar el Tribunal Constitucional. Así, él sostenía que «No es pues el Parlamento mismo con quien puede contarse para realizar su subordinación a la Constitución. Es un órgano diferente a él, independiente de él, y por consiguiente, también de cualquier otra autoridad estatal, al que es necesario encargar la anulación de los actos inconstitucionales —esto es, a una jurisdicción o tribunal constitucional». KELSEN, Hans. La garantía jurisdiccional de la Constitución (La justicia constitucional). Traducción de Rolando Tamayo y Salmorán. México: Universidad Nacional Autónoma de México, 2001, p. 52. 
partido o partidos minoritarios plantean un recurso de inconstitucionalidad, la sentencia del Tribunal, siempre fundamentada en razones jurídicas, si es afirmativa, rectifica la victoria parlamentaria de la mayoría; si es negativa, la ratifica, y entre ambos extremos caben resultados intermedios cuando la sentencia declara constitucionales algunos de los preceptos impugnados e inconstitucionales otros. ${ }^{45}$

Lo dicho por Hesse ${ }^{46}$ sobre el particular resulta también del mayor interés. Y es que para él, «A despecho de lo que decía Schmitt (Schmitt, C. Der Hüter der Verfassung, 1931, p. 22, 31 y ss), sus decisiones son jurídicas [se refiere al Tribunal Constitucional], y no políticas enmascaradas que estén en contradicción de la verdadera jurisprudencia y deban por ello conducir a la politización de la justicia» (las cursivas son nuestras).

Lo expuesto son elementos que nos permiten deducir, en términos generales, que cuando hacemos referencia al Jurado Nacional de Elecciones y al Tribunal Constitucional peruano, estamos hablando de organismos constitucionalmente autónomos.

Ahora bien, actualmente sobre la base de aquella autonomía y la irrevisibilidad de sus decisiones consagrada en la misma Constitución, entre otras razones, nuestro máximo tribunal en lo electoral pareciera gozar de inmunidad de jurisdicción, ${ }^{47}$ esto es que sus decisiones, aun cuando lesionen derechos fundamentales o contravengan, en líneas generales, la norma fundamental, no serían susceptibles de ser cuestionadas a través del amparo.

Convendría tener presente que en varios países de América Latina se ha consagrado la irrevisibilidad de las decisiones del máximo tribunal en lo electoral, incluso frente a procesos que permiten un control de constitucionalidad. ${ }^{48}$ Para algunos es un elemento que pone de relieve la especial importancia que

45 García Pelayo, Manuel. "El "status" del...». Ob. cit., p. 25.

46 HeSSE, Konrad. «La jurisprudencia y la jurisdicción constitucional». En Revista Iberoamericana de Derecho Procesal Constitucional, nº 4. México: Editorial Porrúa, julio-diciembre 2005, p. 164.

47 Convendría revisar sobre el particular García de Enterría, Eduardo. Democracia, ley e inmunidades del poder. Lima: Palestra Editores, 2004, p. 22 y ss.

48 En países como Costa Rica, República Dominicana y Uruguay no se comprende ningún tipo de recurso o proceso contra las decisiones de los tribunales electorales, mientras que en Guatemala, Honduras y Nicaragua, por ejemplo, se admite la posibilidad de cuestionarlas por medio de un amparo. En el caso de El Salvador, es factible interponer amparos, hábeas corpus, así como procesos de inconstitucionalidad, en cambio en Panamá procede solo el Ilamado recurso de inconstitucionalidad. Por último, en Brasil es posible impugnar ante el Supremo Tribunal Federal las decisiones reputadas como inconstitucionales y también las que nieguen las solicitudes de hábeas corpus y de mandado de segurança (que es considerado como equivalente al amparo), mientras que en Bolivia puede acudirse al Tribunal Constitucional por infracción de los preceptos constitucionales. Ver: JARAMILLO, Juan. «Los órganos electorales...». Ob. cit., p. 227. 
reviste a un organismo de esta naturaleza, ${ }^{49}$ para otros es la consecuencia de evitar que los tribunales ordinarios se vean involucrados en las contiendas políticas, así como del afán de rescatar la calificación de las elecciones del ámbito de acción de los parlamentos. ${ }^{50}$ Sin embargo, tales posiciones, como se ha destacado, no están libres de ciertos riesgos que conducen a repensar una fórmula de esta naturaleza, riesgos que, por cierto, en algunos casos han dejado de ser tales y han generado situaciones por lo menos discutibles. ${ }^{51}$

De ahí que, por ejemplo, la Corte Interamericana de Derechos Humanos en el caso "Yatama versus Nicaragua", en sentencia de fecha 23 de junio de 2005, haya establecido en un supuesto semejante al de nuestro país que:

Si bien la Constitución de Nicaragua ha establecido que las resoluciones del Consejo Supremo Electoral en materia electoral no son susceptibles de recursos ordinarios o extraordinarios, esto no significa que dicho Consejo no deba estar sometido a controles judiciales, como lo están los otros poderes del Estado. Las exigencias derivadas del principio de independencia de los poderes del Estado no son incompatibles con la necesidad de consagrar recursos o mecanismos para proteger los derechos humanos.

Independientemente de la regulación que cada Estado haga respecto del órgano supremo electoral, éste debe estar sujeto a algún control jurisdiccional que permita determinar si sus actos han sido adoptados al amparo de los derechos y garantías minimas previstos en la Convención Americana, así como los establecidos en su propia legislación, lo cual no es incompatible con el respeto a las funciones que son propias de dicho órgano en materia electoral. Este control es indispensable cuando los órganos supremos electorales, como el Consejo Supremo Electoral en Nicaragua, tienen amplias atribuciones, que exceden las facultades administrativas, y que podrían ser utilizadas, sin un adecuado control, para favorecer determinados fines partidistas. En este ámbito, dicho recurso debe ser sencillo y rápido, tomando en cuenta las particularidades del procedimiento electoral. (Las cursivas son nuestras).

49 En efecto, se sostiene que «Aun cuando los órganos de los demás países no son definidos constitucionalmente de tal manera, es incuestionable su relevancia debido a su amplísima autonomía constitucional, funcional (sobre todo en aquellos casos en que sus resoluciones tienen carácter definitivo y están al margen de cualquier posibilidad de revisión por algún otro órgano de gobierno, tal como ocurre en Costa Rica, Chile, Ecuador, México, si bien aquí se le coloca dentro del respectivo Poder Judicial, Nicaragua, Perú, República Dominicana y Uruguay) e, incluso, presupuestal». Orozco Henríquez, Jesús. «El contencioso electoral...». Ob. cit., p. 741.

50 Jaramillo, Juan. «Los órganos electorales...». Ob. cit., p. 240.

51 Así, por ejemplo, en República Dominicana las decisiones de la Junta Central Electoral, consideradas como definitivas e inimpugnables, han generado en múltiples ocasiones una que otra protesta y acusación, las cuales pusieron incluso en tela de juicio la imparcialidad de dicho organismo. Eso fue lo que ocurrió en las elecciones presidenciales del año 1978 y el conocido "fallo histórico», que fue calificado en general como arbitrario. Similar situación es la que se presentó en las elecciones de 1994, cuyos resultados fueron tan cuestionados que la única forma de finiquitar tal inconformidad fue celebrando el acuerdo de reducir el periodo presidencial y convocar nuevas elecciones anticipadamente. 
Es más, y por si lo recientemente señalado no fuera suficiente, es menester tomar en consideración que la postura asumida por el Jurado Nacional de Elecciones, admitida luego por el Congreso de la República, no se condice además, con lo que resulta propio de los organismos constitucionalmente autónomos que es, entre otras cosas, su interacción.

En efecto, como habrá podido observar el lector cuando desarrollamos el apartado anterior, en las definiciones de los organismos constitucionalmente autónomos, así como al momento de describir sus características más relevantes, se hace referencia a que este tipo de organismos gozan de una relativa independencia. En otros términos, no es posible sostener que ostentan una autonomía a tal punto que se manejan bajo sus propias pautas sin mecanismos de interrelación, pues ello nos trasladaría más bien a un escenario de autarquía. Y es que "Las funciones de esos órganos son diferentes entre sí ya que implican la razón de ser de cada uno de ellos y la justificación de su independencia relativa, id per relationem, pero a su vez los órganos constitucionales están interrelacionados y coordinados entre sí, porque el Estado es uno». ${ }^{52}$

En ese entendimiento se encuentra un importante sector de la doctrina, cuando sostiene que:

[...] la independencia jurídica del órgano respecto a una voluntad extraña en lo que se refiere al ejercicio de sus competencias no excluye la interdependencia organizativa o sistemática de los órganos entre sí, sino que más bien supone que el producto de la acción de los unos sea condición para la acción de los otros o que, cuando menos, tenga efectos sobre ella. Precisamente una de las funciones de la Constitución es el establecimiento de unas normas que regulen las relaciones de interacción y, por tanto, de interdependencia objetiva entre los órganos instituidos por ella. Al conjunto de estas relaciones destinadas a

Sin ir muy lejos, en Bolivia en el año 1989 el Movimiento Nacional Revolucionario, luego de criticar la actuación de la Corte Nacional Electoral, impugnó las elecciones de aquel año. Así, solicitó a la Corte Suprema de Justicia que decretara la anulación de dichas elecciones, pero en la medida en que la ley electoral en aquel entonces establecía el carácter definitivo, irrevisable e inapelable de las decisiones de la Corte Nacional Electoral, dicha demanda no prosperó.

Por otro lado, en Panamá, aun cuando las decisiones de la corte electoral son susceptibles de ser cuestionadas por razones de constitucionalidad, también hubo ocasión en la cual se puso en cuestión dicho esquema. En las elecciones de 1989 el Tribunal Electoral decretó la nulidad general de los comicios y no convocó a nuevas elecciones. Sostuvo que se habían presentado situaciones que alteraron el resultado final de las elecciones. Contra dicha decisión del tribunal electoral se presentaron dos demandas de inconstitucionalidad ante la Corte Suprema de Justicia; sin embargo, esta las rechazó manifestando que la corte electoral no había ido en contra de ninguna disposición constitucional, actuó, según la Corte Suprema, dentro del margen de acción que la Constitución le ha establecido como propios y añadió que ella no podía entrar a realizar un examen destinado a controlar la legalidad de su actuación. Ibíd., p. 241.

52 Trujlllo Rincón, María Antonia. «Los conflictos entre...». Ob. cit., p. 46. 
conexionar órganos paritarios e independientes in suo ordine, se les suele denominar relaciones de coordinación. ${ }^{53}$

Ahora bien, en el Perú, y como suele ocurrir en varios países, es el Tribunal Constitucional el que ostenta el monopolio de la competencia para decidir sobre el legítimo ejercicio de las atribuciones o funciones por parte de organismos constitucionalmente autónomos, como es el caso del Jurado Nacional de Elecciones. Y no solo eso, sino que es el llamado a tutelar los derechos fundamentales y la supremacía constitucional. En ese orden de ideas, si un organismo constitucionalmente autónomo, cualquier sujeto u órgano del Estado amenaza o lesiona un derecho fundamental o contraviene la norma fundamental, resulta que el supremo intérprete de nuestro texto constitucional es competente para corregir aquella situación. Esto se aplica sin excepción alguna y se extiende, por lo tanto, al Jurado Nacional de Elecciones y es la lógica consecuencia de asumir la Constitución como norma jurídica, ${ }^{54}$ y la aplicación de los criterios de interpretación constitucional de unidad, concordancia práctica, y corrección funcional. ${ }^{55}$ En otras palabras, de asumir la Constitución como

53 García Pelayo, Manuel. «El "status" del...». Ob. cit., p. 28.

54 En efecto, de poco o nada sirve decir que la Constitución no es solo una norma política, sino sobre todo norma jurídica, y, por lo tanto, de obligatorio cumplimiento, si no se tiene a mano un conjunto de mecanismos que permitan corregir aquella situación que no se condice con los planteamientos recogidos en ella. Aquí se pone de manifiesto la estrecha relación que existe entre el carácter normativo de la Constitución y el control de constitucionalidad, tema que ha sido frecuentemente resaltado por la doctrina. En ese orden de ideas, es a todas luces discutible sostener la irrevisibilidad de las decisiones del Jurado Nacional de Elecciones, aun cuando estas lesionan el texto constitucional en general y los derechos fundamentales en particular.

55 Por el criterio de unidad se entiende que la Constitución debe entenderse de modo integral y no como conformada por compartimentos estancos. La consecuencia de la aplicación de este criterio de interpretación constitucional es que el análisis de cada disposición de la norma fundamental debe efectuarse tomando en consideración las demás normas que ella contiene.

El criterio de coherencia y concordancia práctica nos remite a la relación que debe existir entre las diferentes disposiciones constitucionales. Así, no pueden haber contradicciones al interior de la misma Constitución, y para evitarlas justamente hay que interpretar el texto constitucional. De esta manera podrán salvarse aquellas aparentes contradicciones.

Finalmente, con el criterio de corrección funcional busca hacerse especial incidencia en las funciones asignadas por el texto constitucional a los diferentes organismos u órganos del Estado. En ese orden de ideas, el intérprete debe respetar el marco de distribución de competencias consagrado por la Constitución. Puede verse sobre la interpretación constitucional, sus criterios y particularidades: HeSSE, Konrad. Escritos de Derecho Constitucional. Madrid: Centro de Estudios Constitucionales, 1992, p. 31 y ss.; Bidart CAmpos, Germán. La interpretación y el control constitucionales en la jurisdicción constitucional. Buenos Aires: Ediar, 1987, p. 234 y ss.; García BelAUndE, Domingo. "La interpretación constitucional como problema». En Palomino Manchego, José F. y Velásquez Ramírez, Ricardo (coordinadores). Modernas tendencias del Derecho en América Latina. I Convención Latinoamericana de Derecho. Lima: Editora Jurídica Grijley, 1997, p. 99 y ss. 
un todo coherente y armónico, y de respetar la distribución de competencias allí determinada.

Es por ello que, en nuestra modesta opinión, es a todas luces discutible mantener una posición como la que defiende el Jurado Nacional de Elecciones y se encuentra hoy en el Código Procesal Constitucional como consecuencia de la modificación introducida por la ley 28642, ya que rompe con la interacción que inspira a la organización del aparato estatal y genera un escenario de autarquía funcional. Como el Tribunal Constitucional peruano ha dejado sentado

[...] dicha interpretación confunde la autonomía que ha sido reconocida constitucionalmente al JNE (artículo $177^{\circ}$ de la Constitución) con autarquía, pues pretende que sus resoluciones no sean objeto de control constitucional en aquellos casos en los que resulten contrarias a los principios y derechos fundamentales reconocidos en la Carta Fundamental. Lo que equivaldría a sostener que para el JNE, tales principios y derechos no resultan vinculantes..$^{56}$

Es más, el supremo intérprete de nuestra Constitución, en aplicación del artículo VII del título preliminar del Código Procesal Constitucional, ha establecido como precedente que las decisiones del Jurado Nacional de Elecciones que afectan derechos fundamentales no se encuentran exentas de control constitucional a través del proceso constitucional de amparo. ${ }^{57}$

\section{Nota final}

En una coyuntura como la que se vive, con elecciones presidenciales y congresales de por medio, qué duda cabe, es importante revestir a aquellas instituciones directamente involucradas en estos menesteres de todas aquellas garantías que les permitan desarrollar las tareas que le son propias en las mejores condiciones posibles de autonomía y eficiencia.

Parte de esas garantías comprende también el asegurarle a los ciudadanos la posibilidad de acceder a los tribunales en caso de que vean menoscabados sus derechos fundamentales, para que sean estos los que se encarguen, dentro de su ámbito de actuación, de protegerlos y determinar las eventuales responsabilidades. Encontrar el equilibrio entre ambos requerimientos es la tarea que,

56 Véase el fundamento jurídico 29 de la sentencia del Tribunal Constitucional peruano de fecha 8 de noviembre del 2005, recaída en el caso «Pedro Andrés Lizana Puelles» (expediente 5854-2005-PA/TC).

57 En este sentido, el fundamento jurídico 35 de la sentencia del Tribunal Constitucional peruano de fecha 8 de noviembre del 2005, recaída en el caso «Pedro Andrés Lizana Puelles» (expediente 5854-2005-PA/TC). 
creemos, aún queda pendiente y que debe ser atendida no solo prontamente, sino seriamente, sin dejar de lado que así como hay una seguridad jurídica que preservar, también hay derechos fundamentales y un orden competencial que respetar. No hagamos de la autonomía de nuestras importantes instituciones, escenarios autárquicos exentos de control. 